\title{
Keterlaksanaan Penilaian Autentik Mata Pelajaran Fisika SMA Negeri
}

\author{
Tutut Rukmana $^{1} *$, Mundilarto ${ }^{2}$ \\ ${ }^{12}$ Program Studi Pendidikan Sains, Program Pascasarjana, Universitas Negeri Yogyakarta \\ Jalan Colombo No. 1, Karangmalang, Yogyakarta 55281, Indonesia \\ * Korespondensi Penulis. E-mail: tututrukmana@gmail.com
}

\begin{abstract}
Abstrak
Penelitian ini bertujuan untuk: (1) mendeskripsikan keterlaksanaan penilaian autentik pada mata pelajaran fisika SMA Negeri di Kabupaten Sleman Daerah Istimewa Yogyakarta (DIY), (2) mengidentifikasi kendala keterlaksanaan penilaian autentik pada mata pelajaran fisika SMA Negeri di Kabupaten Sleman Daerah Istimewa Yogyakarta, dan (3) mendeskripsikan hubungan kebijakan kepala sekolah dan pelatihan yang telah diterima pendidik terhadap keterlaksanaan penilaian autentik. Teknik pengumpulan data penelitian ini terdiri atas: angket, observasi, dan wawancara terhadap kepala sekolah, pendidik, dan peserta didik. Validitas instrumen penelitian diperoleh melalui expert judgments oleh dosen ahli. Hasil penelitian ini adalah sebagai berikut. (1) Keterlaksanaan penilaian autentik mata pelajaran SMA Negeri di Kabupaten Sleman Daerah Istimewa Yogyakarta kategori baik. (2) Kendala keterlaksanaan penilaian autentik mata pelajaran fisika SMA Negeri di Kabupaten Sleman Daerah Istimewa Yogyakarta meliputi jenis materi, waktu, kondisi sekolah, dan kemampuan pendidik yang dipengaruhi oleh beban kerja pendidik. (3) Hubungan kebijakan kepala sekolah terhadap keterlaksanaan penilaian autentik kategori kuat, dan tidak terdapat hubungan antara pelatihan yang telah diterima pendidik dan keterlaksanaan penilaian autentik.
\end{abstract}

Kata Kunci: keterlaksanaan, mata pelajaran fisika, penilaian autentik

\section{The Feasibility of Authentic Assessment on Physics Subject at State Senior High Schools}

\begin{abstract}
This research aims to: (1) describe the feasibility of authentic assessment on physics subject at state senior high schools in Sleman regency Daerah Istimewa Yogyakarta (DIY), (2) identify the obstacles of the feasibility of authentic assessment on physics subject at state senior high schools in Sleman regency Daerah Istimewa Yogyakarta, and (3) describe the correlation between the headmaster's policy and teacher training to feasibility of authentic assessment. The data were collected through: questionnaire, observation, and interview with headmasters, teachers, and students. The validity of research instrument was measured by expert judgements. The results of this study are as follow. (1) The feasibility of authentic assessment on physics subject at state senior high schools in Sleman regency Daerah Istimewa Yogyakarta is in good category. (2) The obstacles of the feasibility of authentic assessment on physics subject at state senior high schools in Sleman regency Daerah Istimewa Yogyakarta include materials, time, school condition, and teacher's ability which is affected by workload. (3) The correlation between headmaster's policy and feasibility authentic assessment is in strong category, and there is no relationship between teacher training and authentic assessment implementation.
\end{abstract}

Keywords: authentic assessment, feasibility, physics subject

How to Cite: Rukmana, T., \& Mundilarto, M. (2016). Keterlaksanaan penilaian autentik mata pelajaran fisika SMA negeri.Jurnal Inovasi Pendidikan IPA, 2(1), 111-121. doi:http://dx.doi.org/10.21831/jipi.v2i1.8382

Permalink/DOI: http://dx.doi.org/10.21831/jipi.v2i1.8382 


\title{
Jurnal Inovasi Pendidikan IPA, 2 (1), 2016 - 112
}

\author{
Tutut Rukmana, Mundilarto
}

\section{PENDAHULUAN}

Undang-Undang Pendidikan RI Nomor 20 (2003) tentang Sistem Pendidikan Nasional pasal satu menyebutkan bahwa pendidikan merupakan usaha sadar dan terencana untuk mewujudkan suasana belajar dan proses pembelajaran agar peserta didik secara aktif mengembangkan potensi dirinya untuk memiliki kekuatan spiritual keagamaan, pengendalian diri, kepribadian, kecerdasan, akhlak mulia, serta keterampilan yang diperlukan dirinya, masyarakat, bangsa, dan negara. Proses dan tujuan merupakan dasar penyelenggaraan sistem pendidikan. Ungkapan tersebut memberikan gambaran bahwa pendidikan merupakan sistem mendasar untuk memperbaiki kualitas sumber daya manusia yang dapat diamati dalam proses pembelajaran yang dibuktikan dengan pelaksanaan penilaian.

Standar penilaian pendidikan pada Peraturan Pemerintah Nomor 66 (2013) tentang Standar Penilaian Pendidikan digunakan untuk memperbaiki proses pembelajaran. Standar tersebut bertujuan menjamin: untuk perencanaan penilaian peserta didik sesuai dengan kompetensi yang akan dicapai dan berdasarkan prinsipprinsip penilaian; pelaksanaan penilaian peserta didik secara profesional, terbuka, edukatif, efektif, efisien, dan sesuai dengan konteks sosial budaya; dan pelaporan hasil penilaian peserta didik secara objektif, akuntabel, dan informatif. Penilaian tersebut diharapkan dapat membawa informasi kemampuan peserta didik secara holistik dan valid. Dengan demikian penilaian pendidikan sebagai proses pengumpulan dan pengolahan informasi untuk mengukur pencapaian hasil belajar peserta didik.

Cordell \& Fisher (2010, pp. 480-481) menyebutkan bahwa penilaian yang efektif membetuk peserta didik sebagai pebelajar yang bermanfaat dan berfaedah pada tujuan akhirnya. Azim \& Khan (2012, p. 318) menambahkan bahwa penilaian memberikan kesempatan pendidik untuk meninjau hasil kegiatan pembelajaran untuk meningkatkan hasil belajar peserta didik. Dengan demikian kegiatan penilaian dapat digunakan untuk menentukan keputusankeputusan selama proses pembelajaran masih berjalan dan dianggap sebagai upaya mengintegrasikan kegiatan pengukuran hasil belajar dengan keseluruhan proses pembelajaran dan merupakan bagian yang tidak terpisahkan dari keseluruhan proses pembelajaran. Penilaian yang menekankan apa yang seharusnya dinilai baik proses maupun hasil dengan berbagai instrumen penilaian yang disesuaikan dengan tuntutan kompetensi yang ada di SK (Standar Kompetensi) atau Kompetensi Inti (KI) dan Kompetensi Dasar (KD).

Perbedaan standar penilaian sebelumnya merupakan Peraturan Pemerintah Nomor 19 (2005) pasal 25 tentang Standar Nasional Pendidikan mendeskripsikan standar kompetensi lulusan sebagai pedoman penilaian yang meliputi kompetensi untuk seluruh mata pelajaran. Selanjutnya, perbaikan standar penilaian dalam kurikulum 2013 pada Permen dikbud Nomor 104 (2014) mempersyaratkan penggunaan penilaian autentik/authentic assessment. Penggunaan penilaian autentik menjadi lebih khusus pada aspek sikap, pengetahuan, dan keterampilan. Oleh karena itu, perbaikan sistem penilaian menuntut kerjasama sekolah yang terdiri atas kepala sekolah, pendidik, dan peserta didik dalam pelaksanaan penilaian.

Kemdikbud (2013, p. 288) model penilaian menyebutkan bahwa konsep penilaian autentik muncul dari ketidakpuasan terhadap tes tertulis yang lazim dilaksanakan pada era sebelumnya tetapi penilaian tertulis atas hasil pembelajaran tetap lazim dilakukan. Dengan demikian penilaian tertulis dianggap gagal dalam mengukur kemampuan peserta didik secara nyata dan menyeluruh.

Hasil wawancara dengan beberapa pendidik di provinsi Jawa Timur dan D. I. Yogyakarta menunjukkan kemampuan pendidik memberikan nilai pada peserta didik yang menonjol. Pendidik mampu mengategorikan peserta didik yang tertinggi dan terendah. Pendidik memberikan nilai rata-rata pada peserta didik yang dianggap sedang atau dianggap tidak menonjol secara keseluruhan.

Pendidik masih kesulitan melaksanakan perubahan model lama menuju model baru dalam implementasi pembelajaran khususnya pada pelaksanaan penilaian autentik. Hal tersebut ditunjukkan dengan terdapatnya perbedaan kurikulum di beberapa sekolah. Pendidik menyebutkan kesulitan tersebut karena hasil deskripsi keseluruhan peserta didik. Pendidik merasa sulit untuk memperhatikan setiap peserta didik selama kegiatan belajar berlangsung. Pendidik menyebutkan bahwa belum menerima informasi kurikulum dan teknik penilaian dari pendidik inti dengan berbagai kendala yaitu belum seluruh pendidik mendapatkan pelatihan tentang penilaian autentik, sarana, dan padatnya jam kegiatan belajar mengajar di sekolah. 


\title{
Jurnal Inovasi Pendidikan IPA, 2 (1), 2016 - 113
}

\author{
Tutut Rukmana, Mundilarto
}

Newmann et al. (2007, p. 11) menyebutkan bahwa autentik membuktikan bingkai kerja dalam mengajar dan menilai hasil yang dipercayakan pada pengetahuan dari akademik atau keterlibatan penerapan pembelajaran. Azim \& Khan (2012, p. 319) menyebutkan bahwa penilaian autentik merupakan kegiatan menyeluruh dan membutuhkan proses menunjukkan bahwa penilaian tersebut merupakan bentuk penting dalam pendidikan karena memfasilitasi peserta didik mengevaluasi proses pembelajaran dengan banyaknya penilaian yang lengkap, yang menekankan pada metakognisi dan proses informasi sebagai kunci pembelajaran, sehingga peserta didik aktif dan mampu mengemban tanggung jawab.

Penilaian hasil belajar merupakan sesuatu yang penting karena penilaian yang dilakukan secara esensial bertujuan untuk mengukur keberhasilan pembelajaran yang dilaksanakan pendidik dan sekaligus mengukur keberhasilan peserta didik dalam penguasaan kompetensi yang ditentukan. Hal tersebut dapat disimpulkan bahwa pendidik dapat melakukan refleksi dan evaluasi terhadap kualitas pembelajaran yang dilakukan baik terhadap metode, strategi, media, model pembelajaran dan hal lain yang dilakukan dalam proses belajar mengajar itu tepat dan efektif atau sebaliknya.

Frey et al. (2012, p. 14) menyebutkan elemen yang sangat penting yang digambarkan dalam penilaian kelas adalah kedalaman peserta didik terlibat, yaitu mengembangkan atau evaluasi keterampilan dan kemampuan yang melebihi penilaian diri sendiri. Sejalan dengan penelitian MacLeod (2013, p. 9) menegaskan bahwa pembelajaran fisika difokuskan pada kemampuan terbaik peserta didik sebagai perspektif fisikawan dan pendidikan yang memungkinkan hubungan antara isi fisika dan prinsip Science, Tecnhnology, Society, and Environment (STSE) dalam pendidikan. Dapat disimpulkan penerapan penilaian autentik ditunjang selain pendidik sebagai fasilitator, kesiapan dan keterlibatan peserta didik serta sarana pendukung untuk pengembangan keterampilan, dan kebijakan kepala sekolah.

Peraturan Menteri Nomor 13 Tahun 2007 Dimensi kompetensi kepala sekolah meliputi kepribadian, manajerial, kewirausahaan, supervisi, dan sosial. Dimensi kompetensi supervisi terdiri atas kompetensi perencana, pelaksana, dan penindaklanjut hasil supervisi. Keterlaksanaan penilaian autentik pada mata pelajaran fisika sebagai wujud pelaksanaan tugas profesio- nal pendidik di sekolah dengan kepala sekolah sebagai penanggung jawab. Salah satu cara pengamatan penerapan penilaian autentik terlihat pada rapor online telah diterapkan di Jakarta dan Surabaya, meliputi kompetensi inti satu hingga empat dengan deskripsi masing-masing aspek.

Penilaian autentik memiliki berbagai kelebihan. Penilaian tersebut (Nitko \& Brookhart, 2011, p. 254) dapat mengungkap perkembangan dan pertumbuhan peserta didik berdasarkan tujuan secara holistik dan valid. Penilaian tersebut menilai kemampuan untuk melakukan dalam pengetahuan dan ketrampilan. Penilaian hasil belajar peserta didik dalam mata pelajaran fisika merupakan bagian yang tak terpisahkan dari kegiatan dalam proses belajar mengajar fisika di sekolah. Penilaian tersebut idealnya berupa penilaian yang berbasis kelas yang dilakukan oleh pendidik bersangkutan yang memahami betul kondisi peserta didiknya.

Nitko \& Brookhart (2007, p. 254) mendeskripsikan bahwa kegiatan belajar mengajar tidak semuanya dilakukan penilaian. Pendidik yang mengajar membutuhkan ketertarikan dari peserta didik, pengalaman, dan latihan untuk mencapai tujuan pembelajaran. Teknik dan jenis penilaian tersebut dapat dilaksanakan melalui penilaian autentik di sekolah sesuai dengan implementasi Kurikulum 2013. Dengan demikian, pengetahuan tentang teknik penilaian hasil belajar merupakan salah satu kompetensi yang perlu dimiliki seorang pendidik fisika.

Hasil observasi menunjukkan ketidaksesuaian antara materi yang diajarkan dengan penilaian yang dilakukan. Penilaian kegiatan kinerja dilakukan melalui daftar pertanyaan pada tingkat pengetahuan. Pertanyaan belum mencerminkan tujuan dalam penilaian kinerja. Nilai aspek ketrampilan peserta didik dalam laporan hasil belajar diambil dari nilai laporan praktikum bukan dari keterampilan maupun kinerja peserta didik secara nyata dalam kegiatan pembelajaran.

Mundilarto (2012, p. 4) menyebutkan bahwa mata pelajaran fisika di SMA dikembangkan mengacu pada karakteristiknya, yang ditujukan mendidik dan melatih peserta didik mengembangkan kompetensi observasi, eksperimentasi, serta berpikir dan bersikap ilmiah berdasarkan ketentuan yang dibuat satuan sekolah. Uraian tersebut menunjukkan bahwa kegiatan penilaian yang berlangsung di sekolah pada hasil akhir kegiatan pembelajaran melalui tes dan non tes diserahkan kepada sekolah melalui 


\title{
Jurnal Inovasi Pendidikan IPA, 2 (1), 2016 - 114
}

\author{
Tutut Rukmana, Mundilarto
}

standar proses belajar pada aspek sikap, keterampilan, dan pengetahuan diharapkan mendukung karakteristik mata pelajaran fisika.

Hasil Ujian Nasional (UN) SMA IPA (2013-2014) di Provinsi D.I. Yogyakarta pada sekolah yang ditunjuk mengimplementasikan kurikulum 2013 (pilot project) kabupaten Sleman untuk mata pelajaran bahasa Indonesia $=$ 8,16 ; bahasa Inggris $=6,57$; matematika $=6,41$; fisika $=5,79$; kimia $=6,06$; biologi $=6,89$. Hasil tersebut menunjukkan rata-rata nilai terendah pada mata pelajaran fisika. Hal ini menunjukkan bahwa proses belajar mata pelajaran fisika selama tiga tahun diukur dengan tes tertulis selama 120 menit dengan perubahan yang meniadakan nilai minimal untuk kelulusan namun digunakan sebagai pertimbangan masuk jenjang pendidikan selanjutnya. Keikutsertaan peserta didik dalam ujian nasional sebagai syarat kelulusan menegaskan penyerahan kelulusan sebagai hak sekolah, namun hasil UN berpengaruh pertimbangan dalam seleksi masuk perguruan tinggi. Penentuan hasil belajar sepenuhnya diserahkan kepada sekolah dengan standar mata pelajaran fisika yang disesuaikan sekolah masing-masing.

Dilema persyaratan penilaian autentik dalam kegiatan belajar mengajar sesuai pada Permen Dikbud no 104 (2014) namun hasil akhir peserta didik masih dipengaruhi oleh nilai UN. Dengan demikian belum menunjukkan keselarasan antara persyaratan penilaian autentik dengan hasil akhir penilaian

Surat Keputusan Penetapan Kelompok (cluster) dalam rangka Pendampingan Kurikulum (2013) Tahun Anggaran 2013, Surat No: 2647/D2/KP/2013, Tanggal: 31 Juli 2013 menunjuk tujuh SMA Negeri di Kabupaten Sleman DI Yogyakarta yang merupakan barometer pendidikan. Hasil UKG (Uji Kompetensi Guru) pedagogi dan profesional provinsi tersebut menunjukkan nilai tertinggi tetapi rata-rata nilai UN mata pelajaran fisika rendah.

Subadi et al. (2013, p. 112) mendeskripsikan empat masalah yang dihadapi pendidik dalam perbaikan diri profesionalisme pendidik meliputi masalah internal, eksternal, komitmen, dan perhatian pendidik. Uangkapan tersebut menyarankan untuk membuat strategi kebijakan mendirikan sistem pendidikan pengembangan perbaikan kualitas pendidik melalui pelatihan berkelanjutan, konsultasi berdasarkan implementasi dan alternatif pengembangan pendidik profesional. Bakri (2012, p. 9) menyebutkan pengaruh hasil dari model kepemimpinan kinerja sekolah tinggi dibentuk dari pedoman pengelola yang bekerja keras untuk perkembangan sekolah. Uraian tersebut menunjukkan hubungan keterlaksanaan penilaian autentik di sekolah antara kebijakan kepala sekolah, pelatihan yang diterima pendidik.

Berdasarkan uraian tersebut maka dilakukan penelitian "Keterlaksanaan Penilaian Autentik pada Mata Pelajaran Fisika SMA Negeri di Kabupaten Sleman Daerah Istimewa Yogyakarta" yang ditinjau dari kebijakan kepala sekolah dan pelatihan yang telah didapat pendidik. Penelitian tersebut bertujuan untuk: (1) mendeskripsikan keterlaksanaan penilaian autentik mata pelajaran fisika SMA Negeri di Kabupaten Sleman DIY, (2) mengidentifikasi kendala keterlaksanaan penilaian autentik mata pelajaran fisika SMA Negeri di Kabupaten Sleman DIY, dan (3) mendeskripsikan hubungan kebijakan kepala sekolah dan pelatihan yang telah diterima pendidik terhadap keterlaksanaan penilaian autentik.

Keterlaksanaan penilaian autentik oleh pendidik meliputi: persepsi, persiapan, pelaksanaan, dan pelaporan. Keterlaksanaan penilaian autentik beserta kendala ditunjukkan oleh deskripsi data melaui review dokumen, observasi, dan wawancara. Review dokumen pendidik melalui hasil pengembangan penilaian pada perangkat pembelajaran. Observasi pendidik melalui pelaksanaan kegiatan belajar mengajar. Wawancara pendidik melalui kegiatan wawancara sebagai konfirmasi keterlaksanaan penilaian autentik. Jenis penilaian autentik terdiri atas observasi, penilaian diri, penilaian antarteman, tes tertulis, penugasan, penilaian kinerja, penilaian proyek, dan penilaian portofolio.

Pengaruh Kebijakan kepala sekolah merupakan dukungan kepala sekolah terhadap keterlaksanaan penilaian autentik meliputi: kepemimpinan, kebijakan terhadap pendidik, kebijakan terhadap peserta didik, kebijakan terhadap sarana, dan kebijakan terhadap pembiayaan. Pelatihan yang diterima pendidik merupakan keterangan pelatihan yang pernah diterima dan berhubungan dengan penilaian autentik selama lima tahun terakhir. Kriteria pelatihan yang diterima pendidik terdiri atas pendidik sebagai instruktur, pendidik yang pernah mendapat pelatihan, dan pendidik yang belum pernah mendapat pelatihan.

\section{METODE}

Penelitian merupakan penelitian survei dengan menggunakan pendekatan kuantitatif kualitatif mengenai keterlaksanaan penilaian 
autentik mata pelajaran fisika ditinjau kebijakan kepala sekolah dan pelatihan pendidik.

\section{Waktu dan Tempat Penelitian}

Penelitian dilakukan pada tujuh SMA Negeri di Kabupaten Sleman DIY yang dilaksanakan pada bulan Februari 2015 - Mei 2015.

\section{Subjek Penelitian}

Populasi dalam penelitian ini adalah seluruh SMA di Kabupaten Sleman yang telah megimplementasikan kurikulum 2013 sejak tahun ajaran 2013/2014 yaitu SMA A, B, C, D, E, F, G. Pengambilan sampel menggunakan teknik purposive sampling yang didasarkan kriteria tertentu yaitu penerapan Kurikulum 2013 pada sekolah pilot project. Sampel dalam penelitian ini, terdiri atas tujuh sekolah dan seluruh pendidik mata pelajaran fisika kelas XI.

\section{Variabel Penelitian}

Variabel yang digunakan dalam penelitian ini adalah: keterlaksanaan penilaian autentik pada mata pelajaran fisika SMA Negeri di Kabupaten Sleman, kebijakan kepala sekolah, dan pelatihan yang diterima pendidik tentang penilaian autentik dalam Kurikulum 2013.

\section{Prosedur Penelitian}

Teknik pengumpulan data dalam penelitian ini meliputi teknik angket, observasi, dan wawancara. Teknik angket menggunakan instrumen berupa lembar angket. Teknik angket digunakan untuk mengungkap data keterlaksanaan penilaian autentik oleh pendidik, kebijakan sekolah, dan pelatihan pendidik. Teknik observasi digunakan untuk mengamati pelaksanaan penilaian autentik aspek sikap, pengetahuan, dan keterampilan. Observasi meliputi pelaksanaan dan persiapan. Alat pengumpul data observasi meliputi lembar observasi pelaksanaan dan lembar review dokumen ketersediaan perangkat penilaian pembelajaran. Teknik wawancara digunakan untuk mengetahui kesesuaian perencanaan, pelaksanaan, dan kendalanya.

\section{Teknik Analisis Data}

Teknik analisis data menggunakan deskripsi data dan analisis korelasi. Teknik analisis deskripsi digunakan untuk menganalisis data deskripsi data keterlaksanaan penilaian autentik dan kendalanya berdasarkan skor angket pendidik, review dokumen, observasi, dan wawancara. Analisis data yang dilakukan dengan cara (1) menjumlahkan dan mengonversi skala sama skor dari masing-masing variabel dan indikator angket, (2) menghitung rata-rata skor tiap indikator pada angket dan aspek pada lembar review dokumen, observasi, dan wawancara, (3) menghitung rata-rata skor total, (4) menghitung persentase indikator dan aspek, (5) mengategorikan keterlaksanaan melalui skor angket.

Tabel 1. Kriteria Kategori Keterlaksanaan

\begin{tabular}{cc}
\hline Kategori & Skor \\
\hline Rendah & $X<(\mu-1,0 \sigma)$ \\
Sedang & $(\mu+1,0 \sigma) \leq X<(\mu+1,0 \sigma)$ \\
Tinggi & $(\mu+1,0 \sigma) \leq X$ \\
\hline
\end{tabular}

Sumber: (Azwar, 2015, p. 149)

Teknik analisis korelasi digunakan untuk mengetahui hubungan kebijakan kepala sekolah $\left(\mathrm{X}_{1}\right)$ dan pelatihan pendidik $\left(\mathrm{X}_{2}\right)$ dengan keterlaksanaan penilaian autentik (Y). Uji korelasi $\left(\mathrm{X}_{1}\right)$ dan $(\mathrm{Y})$ menggunakan Spearman Rank. Uji korelasi $\left(\mathrm{X}_{2}\right)$ dan $(\mathrm{Y})$ menggunakan Chi Square yang didukung dengan uji beda Kruskal Wallis.

Tabel 2. Interpretasi Koefisien Korelasi

\begin{tabular}{cc}
\hline Interval Koefisien & Tingkat Hubungan \\
\hline $0,000-0,199$ & sangat lemah \\
$0,200-0,399$ & lemah \\
$0,400-0,599$ & cukup \\
$0,600-0,799$ & kuat \\
\hline $0,800-1,000$ & sangat kuat \\
\hline
\end{tabular}

Sumber: Sugiono, (2012, p. 231)

\section{HASIL DAN PEMBAHASAN}

Hasil analisis keterlaksanaan penilaian autentik meliputi indikator persepsi, persiapan, pelaksanaan, dan pelaporan pada Tabel 3 .

Tabel 3. Keterlaksanaan Penilaian Autentik

\begin{tabular}{cccc}
\hline $\begin{array}{c}\text { Kode } \\
\text { Pendidik }\end{array}$ & Skor (total) & Skor $(\%)$ & Kategori \\
\hline A1 & 42 & 48 & Rendah \\
A2 & 50 & 57 & Rendah \\
B1 & 75 & 85 & Baik \\
B2 & 54 & 61 & sedang \\
B3 & 78 & 89 & Baik \\
C1 & 84 & 95 & Baik \\
D1 & 60 & 68 & Baik \\
D2 & 52 & 59 & sedang \\
E1 & 81 & 92 & Baik \\
F1 & 55 & 63 & sedang \\
F2 & 48 & 55 & rendah \\
G1 & 57 & 65 & sedang \\
\hline Rata-rata & 61 & $\mathbf{7 0}$ & Baik \\
\hline
\end{tabular}

Keterlaksanaan penilaian autentik mata pelajaran fisika SMA Negeri di Kabupaten Sleman DIY rata-rata sebesar $70 \%$ berdasarkan skor angket pendidik. Hasil keterlaksanaan 
penilaian autentik mata pelajaran fisika SMA Negeri di Kabupaten Sleman DIY didukung berdasarkan hasil review data, observasi, dan wawancara.

Tabel 4. Indikator Keterlaksanaan

\begin{tabular}{clc}
\hline No & Indikator Keterlaksanaan & $\mathbf{( \% )}$ \\
\hline 1 & Persepsi & 67 \\
2 & Persiapan & 67 \\
3 & Pelaksanaan & 70 \\
4 & Pelaporan & 79 \\
\hline \multicolumn{2}{c}{ Rata-rata keseluruhan } & 70 \\
\hline
\end{tabular}

Persepsi pendidik meliputi tanggapan antusias dan penerapan, persiapan, pelaksanaan, dan pelaporan. Persepsi tersebut terlihat dalam skor angket Tabel 3 dihubungkan dengan perbedaan review dokumen dan observasi Tabel 4.

Tabel 4 merupakan pelaksanaan penilaian autentik pada mata pelajaran fisika SMA Negeri di Kabupaten Sleman melalui review dokumen, observasi, dan wawancara meliputi aspek sikap, pengetahuan, dan keterampilan. Skor review dokumen dari ketersediaan lembar penilaian pada perangkat pembelajaran. Skor observasi dari kegiatan observasi pelaksanaan selama kegiatan belajar mengajar di dalam atau di luar kelas berlangsung minimal tiga kali pertemuan. Skor wawancara didapat dari kegiatan wawancara yang dilakukan kepada pendidik mata pelajaran fisika di luar jam kegiatan belajar mengajar.

Tabel 5. Skor Review, Observasi, Wawancara

\begin{tabular}{cccc}
\hline Kode & Review & Observasi & wawancara \\
\hline A1 & 6 & 7 & 7 \\
A2 & 8 & 8 & 7 \\
B1 & 11 & 8 & 6 \\
B2 & 11 & 12 & 10 \\
B3 & 11 & 6 & 7 \\
C1 & 9 & 12 & 12 \\
D1 & 8 & 12 & 10 \\
D2 & 8 & 10 & 9 \\
E1 & 8 & 12 & 10 \\
FI & 5 & 9 & 7 \\
F2 & 12 & 8 & 11 \\
G1 & 11 & 9 & 11 \\
\hline (\%) & 75 & 78 & 74 \\
\hline
\end{tabular}

Tabel 5 menunjukkan perbedaan hasil skor angket dan observasi pada pendidik kode B (B1, B2, B3) dan kode F2. Pendidik kode B merupakan sekolah dengan pelaksanaan kegiatan belajar mengajar melalui tim pembelajaran. Satu kelas XI diampu oleh dua pendidik dengan pembagian materi dan latihan soal. Kode F2 merupakan pendidik yang memiliki persiapan penilaian perangkat pembelajaran yang baik.
Pengamatan kepada pendidik tersebut dilakukan secara langsung belum memberikan kesempatan pendidik untuk mempersiapkan kegiatan belajar mengajar.

Hasil review dokumen menunjukkan persiapan penilaian dalam perangkat pembelajaran disusun bersama di Musyawarah Guru Mata Pelajaran (MGMP). Pertemuan MGMP oleh pendidik IPA pada pendidik fisika diselanggarakan setiap sabtu pada minggu efektif kegiatan belajar mengajar, sehingga ditemukan hasil persiapan perangkat penilaian dengan beberapa aspek yang sama dan telah disesuaikan dengan kondisi sekolah dan kemampuan masing-masing. Pertemuan rutin tersebut membahas persepsi pendidik fisika dalam inovasi kegiatan belajar mengajar termasuk penerapan penilaian autentik.

Hasil observasi menunjukkan kegiatan penilaian autentik mayoritas melalui penugasan dan tes. Penilaian sikap dilakukan dengan berbagai teknik meliputi dalam kegiatan belajar mengajar, di akhir kegiatan belajar, dan di akhir semester. Penilaian keterampilan dilakukan bergantung pada kondisi sekolah masing-masing. SMAN 2 Ngaglik menunjukkan penerapan penilaian autentik melalui kegiatan praktikum terjadwal selama satu semester pada jam khusus meliputi kinerja, pelaporan, dan uji responsi. SMAN 1 Sleman dan SMAN 1 Pakem menunjukkan penerapan penilaian autentik dengan mengintegrasi program komputer dengan kegiatan fisika melalui pembuatan video yang dipresentasikan dan didiskusikan bersama.

Hasil wawancara menunjukkan kesesuaian antara hasil review dokumen kegiatan observasi. Pendidik mengungkapkan bahwa kegiatan penilaian autentik dilaksanakan berdasarkan kemampuan masing-masing pendidik. Pendidik yang mengampu kelas XI dengan rombel (rombongan belajar) sedikit belum mempersiapkan penilaian karena fokus pendidik tersebut pada UN. Tiga pendidik tersebut dapat dilakukan pengamatan review dokumen, observasi, dan wawancara setelah UN berlangsung. Pendidik selaku instruktur mendeskripsikan bahwa kegiatan penilaian autentik dapat dilakukan secara bersama/tim, sehingga pendidik fokus dalam penanaman konsep dan penilaian autentik peserta didik dapat dibuktikan secara langsung

Tabel 6 menunjukkan hasil rekapitulasi aspek sikap, pengetahuan, keterampilan, dan tindak lanjut melalui review dokumen, observasi, dan wawancara. Aspek pengetahuan dan tindak lanjut memiliki bagian terbesar dalam kegiatan 
belajar mengajar. Aspek sikap dan keterampilan memiliki persentase yang berdekatan.

Tabel 6. Apek Keterlaksanaan

\begin{tabular}{clc}
\hline No & \multicolumn{1}{c}{ Aspek yang diamati } & (\%) \\
\hline 1 & Sikap & 56 \\
2 & Pengetahuan & 97 \\
3 & Keterampilan & 69 \\
4 & Tindak lanjut & 86 \\
\hline & Rata-rata keseluruhan & 77 \\
\hline
\end{tabular}

Kesamaan dalam penilaian keterampilan melalaui kegiatan lomba roket yang antar sekolah sehingga diterapkan oleh tujuh sekolah pilot project. Teknik penilaian melalui obsevasi, angket, dan tugas mendominasi. Sedangkan tindak lanjut bergantung pada kondisi peserta didik baik remidi maupun pengayaan. Perbaikan melalui penilaian autentik dalam kegiatan belajar mengajar selalu dilaksanakan secara tertulis maupun tidak tertulis.

Persiapan terlihat dari observasi dokumen pada hasil lembar review dokumen persiapan penilaian. Kelengkapan persiapan pendidik dalam kategori baik secara administratif. Hal tersebut ditunjukkan dari bentuk persiapan perangkat penilaian yang sama. Reynolds et al. (2009, p. 268) merekomendasikan untuk membatasi pengukuran penilaian autentik pada tujuan pembelajaran yang tidak sesuai. Dengan demikian menunjukkan hasil perencanaan yang dilakukan belum sesuai dengan kemampuan pendidik. Rencana pembelajaran tersebut belum mencakup kriteria, batasan, dan rubrik penilaian.

Pelaksanaan kegiatan belajar mengajar pada materi fisika didominasi pendidik dalam penanaman konsep. Dominasi konsep, persamaan, dan latihan soal pada materi teori kinetik gas dan gelombang. Pendidik memberikan batasan/ rambu-rambu untuk peserta didik melakukan eksplorasi/penjelajahan terhadap materi pemanasan global. Peserta didik memiliki kebebasan untuk memanfaatkan sarana yang ada di sekolah meliputi jaringan internet melalui wifi, perpustakaan, dan lingkungan sekolah. Terdapat kegiatan penilaian dilakukan belum sesuai dengan perencanaan penilaian yang disesuaikan dengan kondisi sekolah.

Pelaksanaan penilaian portofolio dan produk termasuk jarang dilakukan SMAN 2 Ngaglik memberikan penilaian produk membuat roller coaster dengan kriteria tertentu yang ditentukan pendidik. Kegiatan tersebut dilakukan di akhir semester dengan anggota seluruh peserta didik dalam satu rombongan belajar. Triatno (2008, p. 37) mendeskripsikan bahwa pelaksanaan selama dan sesudah proses pembelajaran berlangsung, formatif dan sumatif, keterampilan dan performansi, berkesinambungan, terintegrasi, dan dapat digunakan sebagai feed back. Dengan demikian terdapat perbedaan hasil data antara review dokumen, observasi, dan wawancara karena saat pelaksanaan penilaian autentik tidak sesuai dengan perencanaan yang dilakukan.

Pendidik menjelaskan pelaporan dilakukan dengan teknik yang menghasilkan memudahkan untuk penyekoran yang reliabel. Pelaporan dilaksanakan sesuai kemampuan pendidik dan berdasarkan kriteria ketuntasan minimal yang ditunjukkan melalui wawancara.

Majid (2008, p. 187) mendeskripsikan penilaian autentik terdiri atas proses yang tak terpisahkan dari pembelajaran; mencerminkan masalah dunia nyata; menggunakan berbagai ukuran, metode, dan kriteria yang sesuai karakteristik, dan esensi pengalaman belajar; dan bersifat holistik yang mencakup semua aspek dari pembelajaran (sikap, pengetahuan, dan keterampilan). Perinsip penilaian mengarahkan pendidik untuk menyusun penilaian tersebut secara berencana dan sistematis yang berfungsi sebagai motivasi, belajar tuntas, efektivitas pengajaran dan umpan balik.

Dengan demikian pendidik selalu melakukan perbaikan berdasarkan penilaian dan pengalaman yang ditunjukkan melalui arsip yang selalu bertambah yang diselipkan pada perencanaan sebagai perbaikan selanjutnya.

Kendala pelaksanaan penilaian autentik pada mata pelajaran fisika SMA Negeri di Kabupaten Sleman Derah Istimewa Yogyakarta dianalisis dalam empat indikator yaitu persepsi, persiapan, pelaksanaan, dan pelaporan penilaian autentik oleh pendidik.

Persepsi meliputi tanggapan dan antusias terhadap pelaksanaan penilaian autentik sebesar $67 \%$ pada pendidik yang telah dan belum mendapatkan pelatihan. Pendidik memiliki berbagai persepsi terhadap ketelaksanaan penilaian autentik. Pendidik mendeskripsikan persepsi penilaian autentik yang luas dan menyeluruh, sehingga pendidik melakukan penilaian tertulis/paper and pencil. Kegiatan penilaian tes tulis merupakan bagian dalam penilaian autentik.

Pendidik yang juga sebagai instruktur mendeskripsikan bahwa penilaian autentik sulit dilakukan sehingga diterapkan sesuai kemampuan dan keadaan sekolah. Kesulitan yang dihadapi adalah kegiatan menuliskan hasil penilaian yang secara langsung dalam lembar penilaian. 
Penerapan kegiatan tersebut akan berjalan lancar apabila kegiatan belajar mengajar dilakukan secara berkelompok atau tim. Tes tertulis merupakan bagian penilaian autentik apabila tes tersebut dapat mewakili dan sesuai dengan keterampilan yang diukur.

Persiapan perangkat keseluruhan yang dimiliki pendidik hampir sama dan beberapa pendidik yang mengampu kelas XII belum memiliki persiapan penilaian perangkat pembelajaran. Apabila dibandingkan dengan pendidik yang mengampu kegiatan belajar mengajar pada tingkat yang sama menunjukkan kesiapan dalam perangkat pembelajaran. Pendidik tersebut mampu memberikan variasi jenis penilaian dan persiapan alat dan bahan sebelum kegiatan belajar mengajar.

Dua pendidik mendeskripsikan bahwa pendidik tidak melakukan penilaian autentik. Namun dalam observasi menunjukkan dalam kegiatan belajar mengajar telah melakukan penerapan penilaian autentik secara alami. Dengan demikian persepsi penilaian autentik berbeda setiap pendidik sehingga memengaruhi persiapan perencanaan perangkat penilaian pembelajaran.

Perbedaan dan kelemahan pendidik dalam pelaksanaan penilaian autentik adalah belum secara langsung menuliskan hasil penilaian. Pendidik biasanya melakukan penilaian secara holistik/ menyeluruh di akhir kegiatan belajar mengajar. Pelaksanaan kegiatan belajar mengajar dalam penilaian dipengaruhi oleh jabatan pendidik. Tambahan jabatan memberikan pengaruh dalam kegiatan belajar mengajar. Pendidik juga mendeskripsikan pengaruh tersebut memberikan dampak terhadap peserta didik pada keadaan yang tidak mudah. Keadaan untuk memberikan pelaksanaan kegiatan belajar mengajar yang baik dengan kegiatan yang menutut jabatan tambahan yang dimiliki pendidik.

Nitko (2007, pp. 254-256) mendeskripsikan kelebihan penilaian autentik meliputi penugasan yang mampu menglarifikasi tujuan yang kompleks; mengetahui kemampuan peserta didik untuk mengerjakan, dan konsisten terhadap teori pembelajaran modern pada pengetahuan awal/prior knowlege; keterkaiatan dan integrasi pengetahuan, keterampilan, dan kemampuan; hubungan terdekat dengan kegiatan pembelajaran; pendekatan penilaian yang luas; dan kesesuaian proses dan produk. Hasil wawancara menunjukkan bahwa pendidik mendukung kegiatan penilaian autentik namun pelaksanaan disesuaikan dengan kemapuan. Penilaian auten- tik dapat berjalan dengan bantuan tim pendidik dalam kelas dan kesesuaian jenis materi fisika dengan pemilihan jenis penilaian.

Kekurangan tersebut diantaranya diperlukan kualitas terbaik untuk keahlian penugasan dan penyekoran rubrik; kegiatan menilai dan respon peserta didik memerlukan waktu yang lama; validitas dan reliabilitas hasil penilaian yang kurang; sedikit informasi yang dapat dibuktikan dari penugasan; kelemahan untuk mencapai target pembelajaran dengan baik; penilaian yang menakutkan bagi peserta didik; kemampuan untuk memperhatikan kebudayan dalam kegiatan pembelajaran.

Hasil wawancara menunjukkan pendidik kesulitan mengelola waktu untuk menyekor peserta didik karena aspek yang dinilai cukup luas. Pendidik menyampaikan bahwa sarana sekolah belum mampu memenuhi kebutuhan seluruh peserta didik.

Bubb \& Earley (2005, p. 5) menyebutkan pendidik menghasbiskan seperempat waktunya untuk menyiapkan dan melaksanakan penilian. Pendidik juga diberikan beban kerja yang telah diatur dengan 24 jam seminggu. Hal tersebut memberikan kegiatan penuh selama satu minggu. Jabatan dalam sekolah juga memengaruhi kegiatan keluar kelas. Dampak bekerja terus menerus yaitu pelanggaran dan hidup yang tidak seimbang. Pekerja yang baik mengenali nilai dan efektivitas harga untuk mendukung staf. Pendidik D1 menjelaskan bahwa pendidik yang menyeimbangkan dengan mengganti kegiatan belajar mengajar dengan pendidik lain atau dalam keadaan mendesak dilakukan penugasan mandiri.

Kelengkapan persiapan penilaian perangkat pembelajaran pada pendidik SMAN 1 Seyegan hingga pada tindak lanjut: remidial, pengayaan, dan analisis kegiatan belajar mengajar. Pendidik A1 dan A2 tidak melakukan kegiatan tidak lanjut pengayaan karena peserta didik dianggap belum tuntas, dan kegiatan remidi dilakukan dengan memperbaiki soal yang sama dan belum tuntas. Pendidik secara terus menerus berusaha memperbaiki kegiatan belajar mengajar yang ditunjukkan pada persiapan penilaian pada perangkat pembelajaran yang selalu bertambah dengan inovasi yang dilakukan pendidik.

Jones (1998, pp. 109-110) mendeskripsikan bahwa hubungan pendidik dan peserta didik sangat penting dalam mempengaruhi perilaku dan kemajuan. Jameson (2006, p. 161) menjelaskan bahwa penempatan prioritas tertinggi pada 
kesuksesan peserta didik dan dimensi moral. Singh et al. (2010, p. 3) menyebutkan penyebab kenaikan antusiasme dan kepercayaan diri peserta didik melalui dukungan pembuktian kesempatan dan pembukaan pada kegiatan belajar fisika. Masukan yang diberikan pendidik dalam pelaksanaan penilaian autentik mata pelajaran fisika SMA di Sleman adanya tim pendidik, dukungan sarana dan prasarana, dan tujuan penilaian autentik yang disesuaikan dengan kebutuhan.

Bubb \& Earley (2005, p. 107) mengemukakan bahwa penggunaan agenda rencana kegiatan dalam satu tahun untuk mempertimbangkan beban kerja di sekolah dan keterampilan yang dibutuhkan. Vescio (2007, p. 80) menyebutkan upaya pengaruh dokumen komunitas pendidik profesional termasuk pada kegitan belajar mengajar. Education's (2010, p. 26) menyebutkan rencana pembelajaran tahunan merupakan bukti sarana pengalaman pembelajaran pendidik profesional selama penilaian tahunan.

Dengan demikian kendala dalam keterlaksanaan penilaian autentik meliputi jenis materi, waktu, kondisi sekolah, dan kemampuan pendidik yang dipengaruhi oleh beban kerja pendidik. Masukan pendidik meliputi adanya tim dalam kegiatan belajar mengajar, dukungan sarana pendukung, dan kesesuaian materi pelajaran fisika dengan kebutuhan di lapangan.

Tabel 7. Hubungan Kebijakan dan Pelatihan

\begin{tabular}{ccccc}
\hline No & Korelasi & $\begin{array}{c}\text { Koef } \\
\text { Korelasi }\end{array}$ & Sig & Hubungan \\
\hline 1 & $\mathrm{X}_{1}-\mathrm{Y}$ & 0,781 & 0,013 & kuat \\
2 & $\mathrm{X}_{2}-\mathrm{Y}$ & - & 0,787 & tidak ada \\
\hline
\end{tabular}

Hubungan pelaksanaan penilaian autentik dengan kebijakan kepala sekolah dan pelatihan yang telah diterima pendidik. Angket kebijakan kepala sekolah meliputi lima indikator yaitu kepemimpinan, kebijakan pendidik, kebijakan sarana dan prasarana, kebijakan peserta didik, dan kebijakan pembiayaan yang terdiri atas 24 butir angket valid. Angket keterlaksanaan pendidik fisika meliputi empat indikator yaitu persepsi, persiapan, pelaksanaan, dan pelaporan yang teriri dari 22 butir angket valid.

Selanjutnya angket pendukung merupakan angket peserta didik tentang keterlaksanaan penilaian autentik yang dilakukan pendidik dan kesiapan peserta didik dalam penilaian autentik. Indikator angket keterlaksanaan meliputi jenis pelaksanaan, format penilaian, dan kegiatan yang terdiri atas 20 butir angket. Indikator angket kesiapan meliputi persiapan, kemampuan menunjukkan dan memanfaatkan ketersediaan sarana, dan ketertarikan dalam penilaian autentik terdiri atas 20 butir angket.

Angket hubungan kebijakan kepala sekolah keterlaksanaan penilaian autentik merupakan implementasi kebijakan kepala sekolah Hasil korelasi menunjukkan hubungan positif antar indikator oleh kepala sekolah berkisar 0,781 dibulatkan 0,8 menunjukkan kategori kuat. Hasil tersebut menunjukkan bahwa kebijakan yang dilakukan oleh kepala sekolah dalam keterlaksanaan penilaian autentik baik, saling berhubungan, dan seimbang. Hal tersebut telah memenuhi dengan standar kompetensi profesional kepala sekolah. Dengan demikian semakin tinggi kebijakan kepala sekolah semakin baik ketrlaksanaan penilaian autentik.

Hasil korelasi tersebut menunjukkan hubungan positif dengan mereduksi tiga responden terdiri atas C1, E1, dan G1. Responden tersebut merupakan pendidik yang memahami penerapan penilaian autentik karena pendidik tersebut mengampu kurikulum di sekolah. Tiga tersponden tersebut menunjukkan hubungan/korelasi negatif. Angket keterlaksanaan lebih besar daripada kebijakan tersebut dikarenakan pendidik memahami penilaian autentik dengan pendidik memegang kedudukan/jabatan kurikulum di sekolah dan dukungan kebijakan kepala sekolah yang cukup. Pendidik tersebut juga memberikan inovasi dan trobosan baru dalam penilaian autentik karena inovasi dan trobosan penilaian autentik oleh pendidik sangat baik.

Nurdin, \& Usman (2013, p. 205) menyebutkan bentuk dukungan kepala sekolah berupa loyalitas menjalankan tugas sebagai kepala sekolah. Hal tersebut ditunjukkan melalui kebijakan terhadap pendidik, sarana, peserta didik, dan pembiayaan dalam mendukung keterlaksanaan penilaian autentik.

Lukum (2013, p.78) mendeskripsikan pengertian pembuat kebijakan pada implementasi masih dibatasi pada pemahaman pada peraturan sehingga implementasi belum maksimal. Hal tersebut menjadi pertimbangan kepala sekolah dalam mengikuti peraturan yang diterapkan. Penelitian yang dilakukan terhadap SMA Negeri pada pilot project karena terdapat sekolah swasta yang belum menerapkan Kurikulum 2013. 
Tabel 8. Persentase Pelatihan Pendidik

\begin{tabular}{lcc}
\hline $\begin{array}{c}\text { Kategori Pelatihan } \\
\text { Pendidik }\end{array}$ & $\begin{array}{c}\text { Jumlah } \\
\text { Pendidik }\end{array}$ & $\begin{array}{c}\text { Jumlah } \\
(\mathbf{\%})\end{array}$ \\
\hline Telah pelatihan & 6 & 50 \\
Belum pelatihan & 4 & 33 \\
Instruktur pelatihan & 2 & 17 \\
\hline \multicolumn{1}{c}{ Total } & 12 & 100 \\
\hline
\end{tabular}

Pelatihan yang diikuti pendidik dalam lima tahun terakhir cukup beragam. Pendidik yang telah mendapatkan pelatihan kurikulum 2013 sebesar $50 \%$, pendidik yang belum mendapatkan pelatihan kurikulum 2013 sebesar 33\%, dan pendidik selaku instruktur sebesar $17 \%$ berdasarkan sampel pendidik fisika SMA Negeri di Kabupaten Sleman, sehingga belum seluruhnya pendidik mendapat konsep penilaian autentik.

Tabel 9. Pelatihan dan Keterlaksanaan

\begin{tabular}{|c|c|c|c|c|c|}
\hline \multicolumn{2}{|c|}{$\begin{array}{l}\text { Pelatihan Pendidik } \\
\text { dan Keterlaksanaan }\end{array}$} & \multicolumn{3}{|c|}{$\begin{array}{c}\text { kategori } \\
\text { keterlaksanaan } \\
\text { rendahsedangtingg }\end{array}$} & Total \\
\hline \multirow{4}{*}{$\begin{array}{l}\text { Pelatihan } \\
\text { pendidik }\end{array}$} & belum & 0 & 1 & 3 & 4 \\
\hline & pelatihan & & & & \\
\hline & Sudah & 1 & 1 & 4 & 6 \\
\hline & instruktur & 0 & 0 & 2 & 2 \\
\hline \multicolumn{2}{|c|}{ Total } & 1 & 2 & 9 & 12 \\
\hline
\end{tabular}

Standar penilaian berbasis kelas yang diterapkan pada KTSP tidak berbeda jauh dengan syarat sistem penilaian autentik dalam Kurikulum 2013. Tidak terdapat hubungan dan perbedaan pelatihan yang telah diterima pendidik terhadap pelaksanaan penilaian autentik. Selanjutnya dilakukan Uji beda $\left(\mathrm{X}_{2}\right)$ dan $\mathrm{Y}$ signifikansi 0,562 menunjukan tidak ada perbedaan antara pelatihan pendidik dengan keterlaksanaan penilaian autentik.

Dapat disimpulkan hal tesebut karena pendidik bisa mendapatkan informasi melalui pengalaman penilaian sebelumnya, internet, teman sejawat, guru inti, instruktur, dan kegiatan MGMP.

\section{SIMPULAN DAN SARAN}

\section{Simpulan}

Berdasarkan hasil penelitian dapat disimpulkan. Keterlaksanaan penilaian autentik mata pelajaran SMA Negeri di Kabupaten Sleman Daerah Istimewa Yogyakarta kategori baik. Kendala keterlaksanaan penilaian autentik mata pelajaran fisika SMA Negeri di Kabupaten Sleman Daerah Istimewa Yogyakarta meliputi jenis materi, waktu, kondisi sekolah, dan kemampuan pendidik yang dipengaruhi oleh beban kerja pendidik. Hubungan kebijakan kepala sekolah terhadap keterlaksanaan penilaian autentik kategori kuat, dan tidak terdapat hubungan antara pelatihan yang telah diterima pendidik dan keterlaksanaan penilaian autentik.

\section{Saran}

Bertitik tolak pada kesimpulan hasil penelitian, berikut ini beberapa saran yang berkaitan dengan penelitian ini sebagai berikut. Pemerintah diharapkan membuat peraturan pelaksanaan penilaian autentik melalui surat edaran dan himbauan penerapan penilaian autentik pada mata pelajaran fisika. Pendidik diharapkan menerapkan pelaksanaan penilaian autentik mata pelajaran fisika SMA Negeri sesuai dengan persiapan penilaian perangkat pembelajaran melalui implikasi sesuai peraturan yang telah ditetapkan. Peneliti kendala selama pelaksanaan observasi penilaian autentik di sekolah dapat dikurangi melalui pendekatan dengan warga sekolah.

\section{DAFTAR PUSTAKA}

Azim, S., \& Khan, M. (2012, May). Authentic assessment: An instructional tool to enhance students learning. Academic Research International, 2(3), 314-320. Retrieved July 10, 2014

Azwar, S. (2015). penyusunan skala psikologi (edisi 2). Yogyakarta: Pustaka Pelajar.

Bakri, N. A. (2012). Administrators' leadership effectiveness in high performance schools: A change. International Journal of Economics and Management Sciences, 2(5), 9-15.

Bubb, S., \& Earley, P. (2005). Managing teacher workload, work-life blance wellbeing. Oliver's Yard, London: PCP Paul Chapman Publising.

Cordell, R. M., \& Fisher, L. F. (2010, April 15). Reference questions as an authentic assessment of information literacy. Franklin D. Schurz Library, Indiana University South Bend, South Bend, Indiana, USA, Emerald Group Publising Limited (www.emeraldinsight.com/00907324.htm), 38, 474-481.

Depdiknas. (2003). UU Nomor 20 Tahun 2003 tentang Sistem Pendidikan Nasional.

Depdiknas. (2005). Peraturan Pemerintah Republik Indonesia Nomor 19 Tahun 2005 tetang Standar Nasional Pendidikan. 
Depdiknas. (2007). Peraturan Menteri Pendidikan Nasional Republik Indonesia Nomor 13 Tahun 2007 tentang Standar Kepala Sekolah/ Madrasah.

Depdiknas. (2007). Peraturan Menteri Pendidikan Nasional Republik Indonesia Nomor 20 Tahun 2007 tentang Standar Penilaian Pendidikan.

Education's, t. M. (2010). Teacher performance appraisal - technical requirements manual. Ontarlo.

Frey, et al. (2012, January). Defining authentic classroom assessment. Practical Assessment Research \& Evaluation, 17(2), 1-18.

Jameson, J. (2006). Leadership in post compulsory education, inspiring leaders of the future. Chiswick High Road, London: David Fulton Publishers.

Jones, V. F., \& Jones, L. S. (1998). Comprehensive classroom management (fifth edition). Needham Height, Mass, USA: Allyn \& Bacon.

Kemdikbud. (2013). Model penilaian hasil belajar peserta didik sma (sekolah menengah atas). Kementerian Pendidikan dan Kebudayaan Direktoran Jenderal Pendidikan Menengah Direktorat Pembinaan SMA.

Kemdikbud. (2013). Peraturan Menteri Pendidikan dan Kebudayaan Republik Indonesia Nomor 66 Tahun 2013 tentang Standar Penilaian Pendidikan.

Kemdikbud. (2014). Peraturan Menteri Penddikan dan Kebudayaan Republik Indonesia Nomor 104 Tahun 2014 tentang Penilaian Hasil Belajar oleh Pendidik pada Pendidikan Dasar dan Pendidikan Menengah.

Lukum, A. (2013). Evaluation of science learning supervision on secondary schools. International Journal of Education, 5(4), 61-81.

MacLeod, K. (2013, July 16). Physics education and stse (science, technology, society, and environment): Perspectives from the literature. European $J$ of Physics Education (EJPE), 4(4), 1-12.
Majid, A. (2008). Perencanaan pembelajaran mengembangkan standar kompetensi guru. Bandung: PT Remaja Rosdakarya Bandung.

Mundilarto. (2012). Penilaian hasil belajar fisika. Yogyakarta: UNY Press.

Newmann, et al. (2007). Authentic instruction and assessment (common standarfor rigot and relevance in teaching academic subjects). Chicago: The Iowa Department of Education.

Nitko, A. J., \& Broohart, S. M. (2011). Educational assessment of students, (sixth edition). Boston: Pearson.

Nitko, A. J., \& Broohart, S. M.. (2007). Educational assessment of students (fifth edition). Boston: Pearson Education, Inc.

Nurdin, M., \& Usman, H. (2013). Kepemimpinan Kepala Sekolah Dasar Negeri 1 Taliwan Kabupaten Sumbawa Barat. Jurnal Akuntabilitas Manajemen Pendidikan, 1(2). 205-218

Reynolds, et al. (2009). Measurement and assessment in education. Upper Saddle River, New Jersey: Pearson Education, Inc.

Singh, C., Moin, L., \& Schunn, C. D. (2010). Introduction to physics teaching for science and engineering undergraduates. Journal of Physics Teacher Education, 5(3), 1-34.

Subadi, et al. (2013). A lesson study as a development model of proffesional teachers. International Journal of Education, 5(2), 102-114.

Sugiono. (2012). Stastika untuk penelitian. Bandung: Alfabeta.

Triatno. (2008). Mendesain pembelajaran kontekstual (contextual teaching and learning) di kelas. Jakarta: Cerdas Pustaka Publisher.

Vescio, V., \& Dorene Ross, A. A. (2007). A review of research on the impact of professional learning communities on teaching practice and student learning. Teaching and Teacher Education, (24), 80-91. 